Small nonprofit organizations are also involved. Enersol Associates in Cambridge, Massachusetts, has worked primarily in the Dominican Republic and Central America, while the Solar Electric Light Fund in Washington, DC, founded by one of us (N.W.), is performing a similar role in Asia and Africa. The Solar Electric Light Fund has set up two revolving loan schemes in Sri Lanka, and more recently has arranged to replicate these programmes in western China; there, 200 million rural people are without electricity.

The Sao Paulo Declaration, from a UN-sponsored photovoltaic workshop held in September 1991 , calls for one million photovoltaic home-lighting systems to be installed by 1995 and ten million by the year 2000 . Declarations are one thing, however, realizing them another, and there are several barriers to the dissemination of this technology 4,7 . First, there is the ability of rural populations to afford the relatively high initial cost. New types of financing schemes are needed and additional central sources of capital will have to be identified to provide the backing for local financing. Happily the worldwide awareness of global warming and other environmental problems associated with large hydroelectric projects and conventional fossilfuelled power plants should allow a healthy slice of energy-sector money to be diverted to environmentally benign solar programmes. The World Bank is considering incorporating solar rural electrification into energy lending programmes for India, Sri Lanka and Indonesia.

Because solar electric lighting systems are cost-effective, it is possible to develop applications so that the loans given to purchase the systems can be repaid. Drip irrigation systems, small power tools, sewing machines, office equipment and other light electrical loads can be profitable if the appropriate engineering is done to couple solar electric power to the equipment. Profitable applications leading to quick repayment will allow revolving loan funds to be distributed to larger groups.

A further key to making SSPS available to many people who could not afford the down payments or monthly payments is for public utilities to purchase large numbers of units. Roof- or pole-mounted units would then be leased to rural customers at a nominal monthly rate. Utilities could obtain cheaper financing and components for the systems than can individual consumers or small cooperatives. This approach will

\title{
Photovoltaic-based SSPS
}

SolaR cells convert IIght to direct current electricity. UIght mpinging on single crystal or polycrystalline sillicon wafers enerates hole-electron pairs which are separated at a p-n (the wafer. The separation of charge current In an external clrcult. The current is used to charge a battery placed In the clrcult and the battery, In turn, provides electrical power, on demand, for lights and ather appllances. Indlvidual solar cells are encapsula

A standard roof- or pole-mounted solar module, with Aplcally 36 10-cm-dlameter solar cells charging a car had-acld battery, provides enough power for both houseid fluorescent lighting and a radio and television. For xample, In the troples, the average dally Insolation will ften exceed $5 \mathrm{kWh} \mathrm{m}^{-2}$. Employing a $40 \mathrm{Wp}$ solar module module producing $\mathbf{4 0}$ watts at noon under direct sunght), this Insolation will produce enough electriclty for 3 uorescent lights each operating for $\mathbf{3}$ hours, as well as 3 hours of radlo and 3 hours of television. The solar modules e generally mounted on roof tops or on poles which allow to be turned to maximize dally charge near the p to 5 days of power supply during overcast periods. cally assembled battery charge Indlcators and chargescharge controllers are the key to long battery life. When ers are well-tralned on how to keep their batterles allve not allowing them to over-dlscharge, they become perts at managing their power consumption. High efflency fluorescent d.c. IIght flxtures using electro-polished minlum reflectors and Inverter ballasts minimize lighting wer requirements. For example, one 9-watt fluorescent ube produces as much light as a 50-watt a.c. Incandescent lb.

be tried as part of a Global Environment Facility photovoltaic lighting project underway in Zimbabwe; the project has a budget of $\$ 7$ million.

In addition, there is a pressing need to develop even smaller and cheaper systems. For most rural families, the cost of a 50 watt SSPS is still too high, even if credit can be arranged. In this respect, smaller systems such as the 'solar lantern', which use a smaller solar module and a built-in storage battery to provide power for one good light and a radio, hold high promise. The aim is to produce rugged, durable and efficient systems for less than $\$ 100$.

Other impediments to the spread of SSPS are that rural populations need to be aware of this technology and to develop a trust in its capabilities. In some places, power-delivery institutions have created a self-serving 'myth of electrification', which has it that eventually everyone will be reached by the main power grid. This is not so, and it discourages new investment in alternative technology. Other problems include high tariffs on imported components of SSPS, unexpected national economic difficulties and the lack of adequate after-sales service in rural areas.

As incomes increase and more efficient solar modules become a reality, expandable SSPS with more power output will be required to meet more sophisticated requirements. The technical challenge will be to design devices and appliances that cool, heat and cook, and which are highly efficient in their use of solar power.

Larger systems will be feasible, especially if better methods of energy storage can be devised. This is one of the big challenges. New methods of regulating both charging and discharging promise to lengthen battery life ${ }^{8}$. Imported, long-life, deep-discharge batteries would be more desirable, but at present they are too expensive for most rural households. More efficient capacitive storage batteries will also be useful if the cost can be kept low. Eventually, it may be that other power-storage methods such as flywheel energy accumulators, pumped storage or solarhydrogen energy systems will provide alternatives to batteries. But - and it cannot be overemphasized - cost is the crucial consideration. Unless the improvements can be manufactured cheaply and in high volume, the people most in need of them will not be able to afford them.

For now, however, the success of thousands of small solar photovoltaic electric systems in the field shows that this technology works as it is. Power needs are rapidly increasing and, according to World Bank estimates, meeting the demand for electricity in the developing countries will cost up to $\$ 1$ trillion in the 1990s. Only one-fifth of this amount has been identified ${ }^{1}$. Even rudimentary SSPS, we believe, can go some way towards filling that gap.

Neville Williams is at the Solar Electric Light Fund, 1739 Connecticut Avenue NW, Washington, DC 20009, USA. Ken Jacobson is in the Department of Cell Biology and Anatomy, University of North Carolina, Chapel Hill, North Carolina 27599, USA. Harold Burris is the Global Environment Facility photovoltaic project consultant, United Nations Development Programme, Harare, Zimbabwe.

1. Lovejoy, D. Natural Resources Forum May, 102-110 (1992).

2. Zweibel, K. Harnessing Solar Power (Plenum, New York, 1990)

3. Hubbard, H. M. Science 244, 297-304 (1989)

4. Hankins, M. Solar Rural Electrification in The Developing World. Four Country Case Studies: Dominican Republic, Kenya, Sri Lanka and Zimbabwe (Solar Electric Light Fund, Washington, DC, 1993).

5. Hansen, R. D. \& Martin, J. G. Natural Resources Forum May, 129-144 (1988).

6. Williams, N. Solar Today Nov./Dec., 22-24 (1991). 7. Annan, R. H., Malbranche, P. \& Hurry, S. Strategy for Disseminating/Commercializing Proven Renewable Energy Technologies, 1-13 (United Nations Development Programme, June, 1991).

8. Harrington, S. R. Charge Controller Technology, BOS Workshop, SOLTECH 92, Photovoltaic Systems Research (Sandia National Laboratories, 1992).

NATURE · VOL $362 \cdot 22$ APRIL 1993 